\title{
Railway freight transportation liberalization as a solution for improving client services quality
}

\author{
Yevhen Krykavskyy ${ }^{1}$, Kateryna Stasiuk ${ }^{1, *}$ \\ ${ }^{1}$ Lviv Polytechnic National University, 12 Bandera street, Lviv, 79013, Ukraine
}

\begin{abstract}
Scientific approaches for defining liberalization as a priority trend in rail transport development has been generalized. The main liberalization purpose and goals have been revealed and systematized. The international experience in rail freight traffic liberalization has been analyzed and conclusions about its efficiency have been made based on statistical data. The basic prerequisites for performing the reformation of rail freight transport in Ukraine by means of liberalization have been revealed. The existing form of transportation process organization at JSC "Ukraine Railways" has been described. A thorough analysis of statistical data characterizing the operational results of the main railway enterprise in Ukraine has confirmed existing problems in the industry that can be resolved through the liberalization process. A survey has been conducted for the main railway customers and a conclusion based on the obtained results has been made considering liberalization necessity for improving customer service quality. A plan of further actions for freight transport liberalization has been proposed.
\end{abstract}

\section{Liberalization essence and goals}

Liberalization is a priority direction for Ukrainian rail transport development in the near future. Currently, the railway industry is in reforming process in order to bring its activities in line with European Union requirements.

According to world experience, the market liberalization is primarily connected with its demonopolisation and deregulation. Liberalization process involves reducing the state's influence on the industry and creating favorable conditions for competition. The EU's actions are aimed at providing complete liberalization, where the state role includes exclusively legislative and regulatory aspects as well as the sphere of transport infrastructure management. Detailed rules and the whole process of liberalization are described in numerous directives and laws for European rail transport. The main purpose of the railway market liberalization is to create competition by stimulating new business entities entry into the market. Developing effective intra-industry competition involves rail transport preparation for competitive actions in the inter-industry market in future.

Liberalization involves separating the traditional organizational structure of rail transport into two zones: management and operational. The main tasks for the unit performing railway infrastructure management functions are infrastructure building and

* Corresponding author: kuzyk.katheryna@gmail.com 
maintenance, responsibility for trains movement using available railroads, real estate included in the railway infrastructure management, railway transportation security, accompanying services provision for railroad travels. Operational area of railway transportations market is form by carriers in competitive conditions. Liberalization processes result is transparent competition, market pricing and improved reliability and quality for entire transportation chain.

\subsection{Worldwide experience in railway freight transportation liberalization}

Global liberalization of railway transportation began in 1990's and nowadays it is possible to sum up the positive effect of these processes.

Let us consider the results of rail freight traffic liberalization on the example of Germany. In 1994, Germany was one of the first to start liberalization process, and in 1995, the first private operator entered railways market. This result proves to be positive because in such a short time the country was able to introduce qualitative mechanisms for market competition creation. It is known that it was in 1990s when German state railway monopoly was in crisis, and that liberalization brought the expected profits (Deutsche Bahn AG's revenues grew by $174 \%$ ). Railway transport market is increasing every year, and now there are about 450 private operators operating in the market. The main performance indicators for rail freight industry in Germany after liberalization are shown in fig. 1.

Licensed operators number in the market

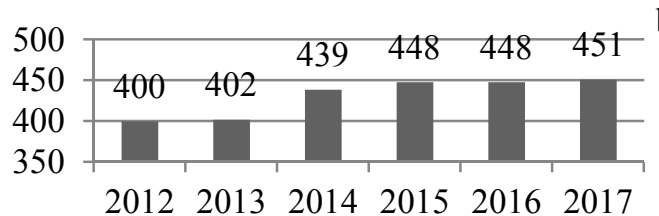

Revenues in the freight railway market (€ billion)

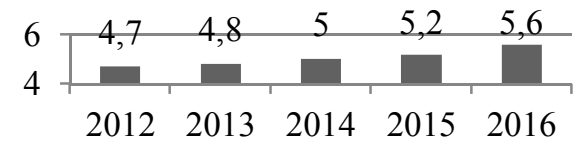

Development of transport volumes broken down by type of transport service (million tons of freight)

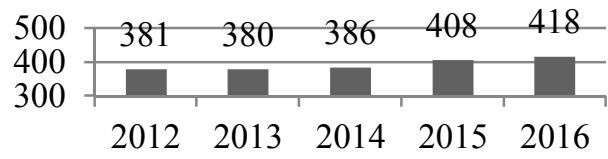

Number of railway undertakings (freight transport)

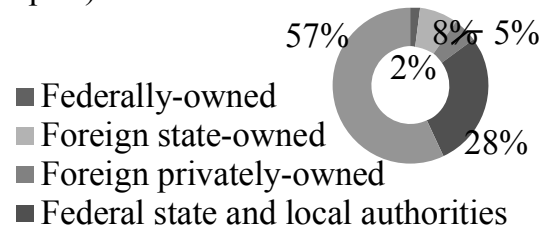

Breakdown of the infrastructure access charges of the railway undertakings (shares in percent)

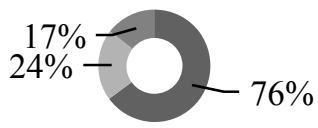

Fig.1. Main indicators for German rail freight industry after liberalization [systematized by authors on the basis of 1]

Data demonstrated in Fig. 1 shows positive results of liberalization in Germany, including: operators number on the market is 451; freight traffic revenue increases annually; cargo transportation volumes show positive dynamics; the market is represented by different private, state or foreign carriers; adjusted infrastructure usage mechanism and income derived from its usage and other services. A survey for German carriers about railway transportation market shows, that it is characterized by the following factors: customer orientation, non- 
discriminatory pricing system, access to infrastructure, international activities, industry development.

\subsection{Rail freight liberalization importance for improving customer service quality}

Liberalization process makes it possible to make rail transport more dynamic, increase investment and attract transit traffic. One more advantage is service quality improvement for shippers / cargo owners, because carriers will compete for the client. Today, in terms of economy and environmental friendliness, rail transport has advantages, but because of low supplies reliability and their regularity, railways are inferior to road freight transport. Customers often complain about rail transportation conditions. New rules will prevail on the market after liberalization providing possibility to change this situation. From the customer's point of view, these new rules mean lower shipping costs, service quality, client-oriented management, railway freight transportation scope expanding, existing problems elimination and railway development in general.

Today, rail transportation has to meet high requirements of customers in order to maintain a competitive position in transport services market. Customers are a valuable resource, and therefore working with them requires proper approach.

In this case, the object of research is freight rail transportation area of JSC "Ukrainian Railways". Certainly, the enterprise activities volumes in this area are very large, so only indicators important for liberalization are selected for this article.

\section{The freight rail transportation area of JSC "Ukrainian railways" - results of the study}

The project of sustainable development logistics strategy of Ukraine [2] identifies the main problems of the railway industry and proposes recommendations for addressing these problems. The main objective is rail freight transport liberalization. In other words, it is a process of establishing a public-private partnership through transferring some services that accompany the transportation process to suborder, contractual access to the railway infrastructure, encouragement for private operators to manage the transport process and repair the rolling stock. In addition, part of investment will come from the private sector, stressing the need to replace most current government decisions in favor of market development and competition, especially in the field of freight traffic.

Railways of Ukraine reforming is carried out in accordance with the State target program for rail transport reforming for 2010-2019 [3] and remains the main task for today and medium term. The main purpose for rail transport reforming is to develop competition in railway transport market and increase industry efficiency. In order to introduce a market model for rail transport functioning, it is necessary to create an effective mechanism of intraindustry competition based on liberalization policy, which involves access to potentially competitive sectors. Ukraine follows a European liberalization path, based on the principle of infrastructure management and transport process separation.

Reformation should relate to changes not only in the organizational but also in the financial model of the rail transport market, as this is a prerequisite for ensuring equal access to the railway infrastructure [4,5]. Open access to Ukraine's railways infrastructure should result in providing an opportunity to receive new and better-quality services from private market operators.

The main railway company operating causes fair complaints from customers, which undoubtedly indicates the existence of more complex, systemic barriers to its further 
development. A survey was conducted for the main freight transportation clients of the regional affiliate "Lviv Railways". 18 major customers attended this survey in 2017. The results are presented in Fig. 2.

Why did you choose to cooperate with RA "Lviv What is of greatest importance to you in Railways":

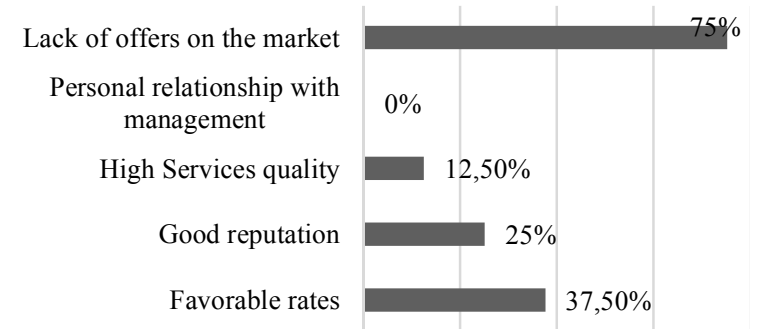
cooperation with "Lviv Railways":

During cooperating, your opinion about RA "Lviv Railways":

- Did not

change

- Changed for

better

- Changed for
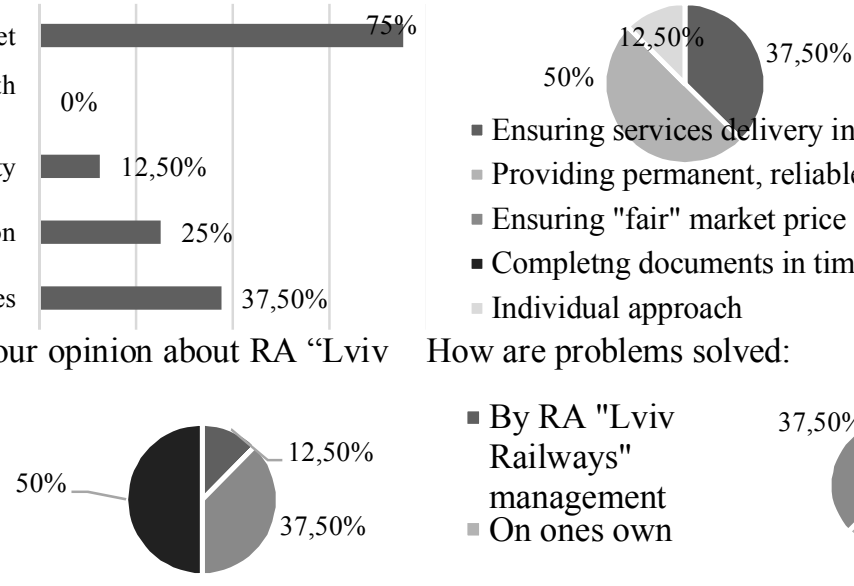

- Ensuring services delivery in time

- Providing permanent, reliable service

- Ensuring "fair" market price for services

- Completng documents in time

Individual approach

How are problems solved:

worse

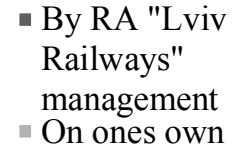

By RA "Lviv

Railways"

- On ones own

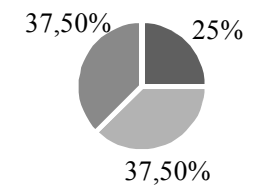

Estimate the general quality level of freight transportation services provided by "Lviv Railways":

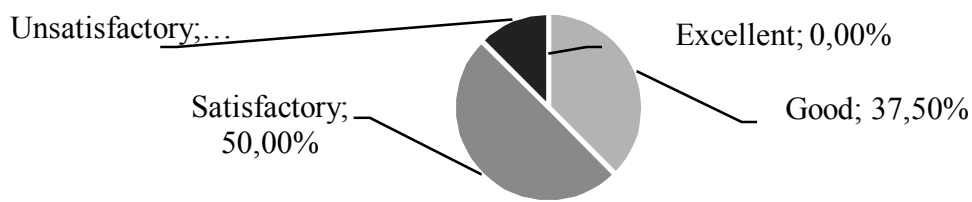

Do you consider the option of changing transport type for your transportations:

Do you know what liberalization of rail

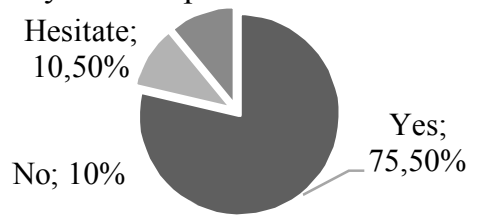
transportation is?
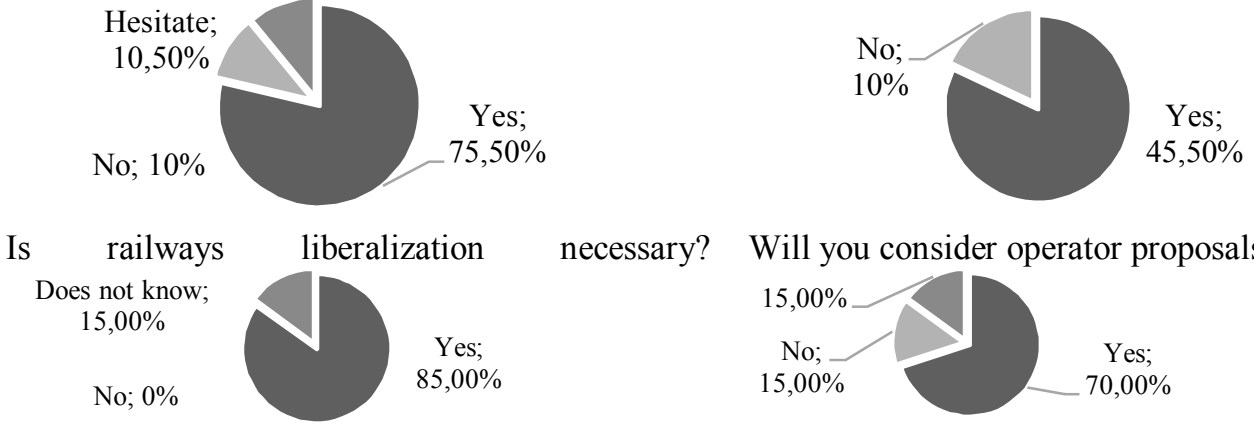

Fig.2. Poll results for "Lviv Railways" clients. [authors research]

The survey results revealed that most of the cooperation with RA "Lviv Railways" is chosen because of the lack of other offers on the market (75\%). The most important reason for clients cooperation with RA is the provision of a permanent, reliable service $(50 \%)$. The most often problems encountered by customers are: delayed delivery of cars, faulty equipment, insufficient equipment / employees to provide services in peak periods, employee incompetence. The following services are assesses as "excellent": employees' attitude and goods safety, a high appreciation was also expressed for information availability and documents processing process. During cooperation period, the opinion on RA "Lviv 
Railways" is constantly changing for $50 \%$ of customers and changes to worse for $37.5 \%$. It was revealed that in $37.5 \%$ of cases clients' problems are solved on their own. The general level of freight transportation services quality for RA "Lviv Railways" is estimated as satisfactory (50\%). RA "Lviv Railways" clients are not satisfied with service quality, because $75.5 \%$ will consider alternative transport types. The study also aimed at clarifying the awareness level and customer attitude towards the liberalization process. Only $45 \%$ of clients understand exactly what liberalization is. Rail freight transportation liberalization necessity is estimated at $85 \% .70 \%$ of respondents will consider private operator proposals. Clients consider these main advantages for liberalization: carrier choosing possibility, delivery reliability, state influence reducing, optimal tariffs, rolling stock condition improving and equipping. Polled clients' expectation for liberalization: market pricing, quality service, constant meeting demand for transportation, transportation process improvement, problems with rolling stock solution, reduction of bureaucracy in the course of transportation.

Therefore, the following conditions for liberalization can be formed based on the analysis of rail freight transportation area:

1. At present, JSC "Ukrainian Railways" is the only enterprise in Ukraine, having railway infrastructure legally fixed, the exclusive competence of which by laws include transportation process regulation in domestic and international communications, and owns both traction rolling stock (main locomotives) and wagons.

2. Transportation process management in domestic and international communications falls within the competence of JSC "Ukrainian Railways".

3. JSC "Ukrainian Railways" occupies a dominant position in the market of main cargo locomotives provision within Ukraine with a share of $100 \%$.

4. In recent years, JSC "Ukrainian Railways" has received appeals from business entities regarding the possibility to obtain permission to use their main cargo locomotives on public roads.

5. The methodology used by JSC "Ukrainian Railways" for calculating costs of their own cars using is imperfect.

6. Market participants - the operators of rolling stock and shippers, consider the main barrier for entering railway transportation market to be impossibility, according to the current legislation, to use own traction rolling stock (locomotives) for the carriage by railways of general use, what means no possibility for carrying out independent transportation of clients' goods.

7. JSC "Ukrainian Railways" is the only carrier to use general railways on the territory of Ukraine. Public transportation by railways with private locomotive draft is not allowed. All forwarding companies provide their services directly through JSC "Ukrainian Railways"; therefore, there can be no real competitors in the market of freight rail transportation for JSC "Ukrainian Railways".

8. At present, the state of JSC "Ukrainian Railways" rolling stock does not meet user requirements; therefore, demand for transportation is not fully satisfied.

9. Rail freight users are not satisfied with service quality of the transportation process and are ready to consider alternative transport types.

Liberalization is not a panacea for all railroad problems, but in addition to reducing the financial and time costs for railways, the improvement of the rail system will reduce the negative effects of motor vehicles excessive use, including traffic congestion, road degradation, emissions and accidents. In the long term, efforts may be directed towards improving intermodal services and developing comprehensive service offerings for shippers that could cover the entire supply chain within Ukraine and partly at the international level.

\section{Conclusions}


Current state of the industry has been described and analyzed, a research has been conducted resulting in forming preconditions and justifying necessity for reforming the industry by implementing liberalization process. A further action plan proposals:

- improve the new edition of the Law of Ukraine "On Railway Transport" in accordance with the requirements of the Railway Transport Directives of the EU (provisions should promote the introduction of competitive conditions for the market, identify the infrastructure operator, approve the mechanism for new entrants to enter the market, etc.);

- create an independent regulator in rail transportations field;

- adjust the reform terms and contents in accordance with the requirements of EU directives;

- carry out locomotive traction and fleet of freight cars market demonopolization (creation of proper legislative base and issuance of permits for private rolling stock usage);

- process business entities proposals regarding their participation in freight locomotives updating and repairing.

Further research will be associated with a more detailed liberalization consideration as one of the priority directions for rail transport development.

\section{References}

1. Market Analysis Railway 2017 /Section 702 -Rail Regulation Economic Policy, Market Watch, Statistics (2017)

2. Website «Ukrainian Railways». Retrieved form https://www.uz.gov.ua/en/ (05.06.2019)

3. State target program of rail transport reform for 2010-2019. Retrieved form https://zakon.rada.gov.ua (05.06.2019)

4. Łakomy-Zinowik, M. Public-private partnership as an alternative source of financing of public tasks. Ekonomia i Prawo. Ecomomics and Law, 16(1): 75-86 (2017)

5. Turgut Ozkan, Gozde Yanginlar, Salih Kalayci Railway Transport Liberalization: A Case Study of Various Countries in the World Journal of Management and Sustainability 6, 4 (2016) 